\title{
MENINGKATKAN HASIL BELAJAR SISWA DENGAN METODE CRITICAL INCIDENTP PADA MATA PELAJARAN FIKIH DI SEKOLAH DASAR
}

\author{
Suparlan \\ STIT Palapa Nusantara \\ maniahparlan66@gmail.com
}

\begin{abstract}
Critical incident strategy (Important Experience) is a strategy to activate students since the start of learning, namely a strategy in which students must remember and describe their past experiences in accordance with the topic of the material presented. The critical incident strategy (important experience) is a strategy in which students must remember and describe their past experiences that are interesting and related and related to the subject to be delivered, then the teacher conveys the material by connecting the experiences possessed by students. According to the Indonesian dictionary, the result is something that exists (bappens) by a job, is successful. Meanwhile, according to R. Gagne, results are seen as internal abilities that belong to people and that people do something. While the understanding of learning is etymologically learning to learn from the word "ajar" which gets the prefix ber and is a verb which has the meaning of trying to gain intelligence.
\end{abstract}

Keywords: Critical Incident Method, Learning Outcomes, Fiqh Learning

\begin{abstract}
Abstrak : Strategi critical incident ( Pengalaman Penting) adalah strategi untuk mengaktifkan siswa sejak dimulainya pembelajaran yaitu strategi yang mana siswa harus mengingat dan mendiskripsikan pengalaman masa lalunya yang sesuai dengan topik materi yang disampaikan. Strategi critical incident (pengalaman penting) yaitu suatu strategi yang mana siswa harus mengingat dan mendiskripsikan pengalaman masa lalunya yang menarik dan berhubungan serta berkaitan dengan pokok bahasan yang akan disampaikan, lalu guru menyampaikan materi dengan menghubungkan pengalaman yang dimiliki oleh siswanya. Menurut kamus bahasa Indonesia hasil adalah sesuatu yag ada (terjadi) oleh suatu kerja, berhasil sukses. Sementara menurut R.Gagne hasil dipandang sebagai kemampuan internal yang menjadi milik orang serta orang itu melakukan sesuatu. Sedangkan pengertian belajar secara etimologis belajar belajar dari kata "ajar" yang mendapat awalan ber- dan merupakan kata kerja yang mempunyai arti berusaha memperoleh kepandaian.
\end{abstract}

Kata Kunci: Metode Critical Incidentp, Hasil Belajar, Pembelajaran Fikih 


\section{PENDAHULUAN}

Undang-Undang pendidikan RI No.20 tahun 2003 Bab II pasal 3 yang berbunyi: "Pendidikan nasional berfungsi menggambarkan kemampuan dan pembentukan watak serta peradaban bangsa yang bermanfaat dalam rangka mencerdaskan kehidupan bangsa, bertujuan untuk mengembangkan kemampuan peserta didik agar menjadi manusia yang beriman dan bertaqwa kepada Tuhan Yang Maha Esa, berakhlak mulia, sehat, berilmu, cakap, kreatif dan menjadi warga Negara yang demokratis serta bertanggung jawab ".

Sebagai mana yang di katakan bahwa pendidikan adalah factor yang yang penting untuk mengembangkan SDM, maka sangat jelas bahwa pendidikan pada dasarnya adalah usaha sadar untuk menumbuh kembangkan potensi sumber daya manusia peserta didik dengan cara mendorong dan memfasilitasi kegiatan belajar mereka, secara detail seperti apa yang telah tercantum dalam undang-undang RI No. 20 Tahun 2003 Bab 1, bahwa "Pendidikan didefinisikan sebagai usaha sadar yang terencana untuk mewujudkan suasana belajar dan proses belajar agar peserta didik secara aktif mengembangkan potensi dirinya untuk memiliki kekuatan spiritual keagamaan, pengendalian diri, kepribadian, kecerdasan, akhlak mulia serta keterampilan yang diperlukan dirinya, masyarakat, bangsa dan Negara”. ,Dalam hal ini tentu saja diperlukan adanya pendidik yang profesional terutama guru disekolah dasar, menengah, dan dosen. ${ }^{2}$

Pendidikan begitu pentingnya dalam kehidupan manusia, maka diatur sedemikian rupa agar dapat membantu kehidupan manusia, semua hal dan komponen yang berhubungan dengan pendidikan selalu diperhatikan cacat yang dapat membuat pendidikan terganggu yang akhirnya tidak sesuai dengan harapan awalnya.dan dipertimbangkan agar tercipta pendidikan yang bermutu mulai dari peserta didik, pendidik, apa yang diajarkan sampai pada masalah sarana prasarana diatur sedemikian rupa agar tidak ada cela dan cacat yang dapat membuat pendidikan terganggu yang akhirnya tidak sesuai dengan harapan awalnya. ${ }^{3}$

Dalam sebuah pendidikan, banyak sekali hal hal yang sangat mempengarui berhasil tidaknya suatu pendidikan itu, antara lain adalah proses belajar mengajar,

\footnotetext{
${ }^{1}$ Undang-undang RI, Tentang System Pendidikan Nasional, (Bandung: Citra Umbara, 2003),hal. 6

2 Muhibbin Syah, Psikologi Belajar, (Jakarta: Raja Grafindo Persada, 2002), hal. 1

3 Amir Daien Indrakusuma, Pengantar Ilmu Pendidikan, (Surabaya: Usaha Nasional, tt), hal. 30
} 
padahal selama ini salah satu yang dihadapi oleh pendidikan kita adalah lemahnya proses pembelajaran, selama ini Sebagian besar pendekatan pendidikan di sekolah-sekolah berpusat pada guru yang berarti semua mengarah pada guru. Karena guru hanya menuntut agar siswanya menerima semua materi yang disampaikan dan berhasil dalam ujian tanpa memperhatikan sisi lain kebutuhan siswa. Untuk mengaktualisasikan diri mengembangkan semua potensi yang dimiliki, mengembangkan daya nalar dalam mengembangkan pengetahuan yang diterima.

Pada abad 20, teacher centered method tidak mampu lagi mendorong motivasi siswa kepada tujuan-tujuan utama pendidikan yaitu : "Kesanggupan berpikir secara kritis dan positif, perkembangan disiplin diri, bekerja sama dengan orang lain secara efektif, bertanggung jawab diri sendiri dan orang lain". ${ }^{4}$

Selain pendekatan strategi dan strategi pembelajaran merupakan prinsip-prinsip yang mendasari kegiatan dan mengarahkan perkembangan peserta didik dalam proses pembelajaran memegang peranan penting dalam menciptakan mutu pendidikan dan hasil belajar yang maksimal. ${ }^{5}$ Para ahli teori teori belajar telah mencoba mengembangkan berbagai cara pendekatan system pengajaran atau proses belajar mengajar, berbagai system pengajaran yang menarik akhir-akhir ini diantaranya adalah strategi pembelajaran aktif.

Pembelajaran aktif adalah suatu pembelajaran yang mengajak peserta didik belajar secara aktif, ketika peserta didik belajar dengan aktif, berarti mereka yang mendominasi aktifitas pembelajaran dan mereka secara aktif menggunakan otak baik untuk menemukan ide pokok dari materi pelajaran, Memecahkan persoalan, atau mengaplikasikan apa-apa yang baru mereka pelajari kedalam suatu persoalan yang ada dalam kehidupan nyata. Dengan belajar aktif ini, peserta didik diajak untuk turut serta dalam semua proses pembelajaran, tidak hanya mental akan tetapi juga melibatkan fisik, dengan cara ini biasnya peserta didik akan meraskan suasana yang lebih menyenangkan sehingga hasil belajar bisa dimaksimalkan. ${ }^{6}$

\footnotetext{
${ }^{4}$ Koestoer Partowisastro, Dinamika Dalam Psikologi Pendidikan,(Jakarta: Erlangga,1983), hal. 79

${ }^{5}$ Melvin L Silberman, Active Learning 101 Cara Belajar Siswa Aktif, (Bandung: Nusa Media, 2006), hal. 02
} 
Strategi pembelajaran aktif menyebutkan empat puluh empat model strategi pembelajaran aktif yang dapat digunakan oleh pendidik, dan salah satu strategi yang mengaktifkan siswa mulai dalam proses belajar mengajar adalah strategi critical incident (pengalaman penting) yaitu strategi untuk mengaktifkan siswa sejak dimulainya pembelajaran yang mana siswa harus mengingat dan mendiskripsikan pengalaman masa lalunya yang sesuai dengan topic materi yang disampaikan. ${ }^{7}$ Dengan strategi ini peserta didik terlibat langsung secara aktif dan dapat membantu siswa dalam berkonsentrasi, mengajukan pendapat, bertanya dan menjawab pertanyaan, serta menggugah diskusi. ${ }^{8}$

Strategi critical incident ( Pengalaman Penting) adalah strategi untuk mengaktifkan siswa sejak dimulainya pembelajaran yaitu strategi yang mana siswa harus mengingat dan mendiskripsikan pengalaman masa lalunya yang sesuai dengan topik materi yang disampaikan. ${ }^{9}$

\section{Strategi Critical Incident (pengalaman penting)}

\section{Pengertian}

Strategi critical incident (pengalaman penting) yaitu suatu strategi yang mana siswa harus mengingat dan mendiskripsikan pengalaman masa lalunya yang menarik dan berhubungan serta berkaitan dengan pokok bahasan yang akan disampaikan, lalu guru menyampaikan materi dengan menghubungkan pengalaman yang dimiliki oleh siswanya. ${ }^{10}$

\section{Tujuan Strategi Critical Incident (pengalaman penting)}

Setiap strategi pasti mempunyai tujuan masing-masing, adapun Tujuan dari strategi critical incident (pengalaman penting) ialah untuk melibatkan peserta didik aktif sejak dimulainya pembelajaran dengan meminta peserta didik untuk mengungkapkan pengalaman yang mereka miliki. ${ }^{11}$ Hal ini juga serupa dengan apa yang di tulis Ahmad

\footnotetext{
${ }^{7}$ Syaharuddin, http :/syaharuddin. Wordpress.com/2008/04/25/mengurrangi kebosanan siswa melalui berbagai strategi mengajar /

${ }^{8}$ Hisyam Zaini, hal. 2

${ }^{9}$ Syaharuddin,

10 http :/syaharuddin. Wordpress.com/2008/04/25/mengurrangi kebosanan siswa melalui berbagai metode mengajar /

${ }^{11}$ Dede Rosyada, et. al., Pendidikan Kewargaan, (Jakarta: Prenada Media,2004 ), hal. 25
} 
Sabri dalam bukunya strategi belajar mengajar dan micro teaching bahwa stratgi ini mempunyai tujuan untuk melihat siwa sejak awal dengan melihat pengalaman mereka. ${ }^{12}$

\section{Langkah-Langkah Pembelajaran Stratei Criical Incident}

Strategi critical incident (pengalaman penting) dalam penerapannya mempunyai langkah-langkah atau prosedur-prosedur yang harus dijalani, antara lain :

a Guru meminta siswa untuk mempelajari topik atau materi yang akan dipelajari disekolah.

b Guru menyampaikan kepada peserta didik topic atau materi yang akan dipelajari dalam pertemuan hari ini.

c Guru meminta kepada peserta didik untuk mengingat-ingat pengalaman mereka yang tidak terlupakan yang sesuai dan berhubungan dengan materi yang akan disampaikan.

d Guru memberikan kesempatan beberapa menit kepada peserta didik untuk Berfikir tentang pengalaman mereka.

e Guru meminta peserta didik untuk mengungkapkan pengalaman mereka yang berhubungan dengan materi yang akan disampaikan pada pertemuan hari ini.

f Guru menyampaikan materi dengan mengaitkan pengalaman-pengalaman yang telah diungkapkan oleh peserta didik. ${ }^{13}$

\section{Kelebihan Dan Kekurangan Strategi Critical Incident}

Strategi critical incident mempunyai kelebihan dan kekurangan antara lain; strategi ini sangat cocok jika diterapkan untuk materi-materi yang bersifat praktis seperti materi sholat, tetapi strategi ini tidak cocok digunakan untuk materi yang bersifat teoritis. ${ }^{14}$

Strategi ini juga mempunyai kelebihan yaitu untuk mengaktifkkan siswa sejak dimulainya pembelajaran. ${ }^{15}$ Selain itu strategi ini baik digunakan untuk tujuan pembelajaran yang mengajarkan peserta didik untuk lebih berempati, strategi ini juga

${ }^{12}$ Ahmad Sabri, Strategi Belajar Mengajar dan Micro Teaching, (Ciputat: Quantum Teaching, 2005), hal. 122

${ }^{13}$ Hisyam Zaini, 2

14 http://ghufroon-nuddaroin.blogspot.com/2009/02/manajemen-pembelajaran.html.

15 Suwardi, Manajemen Pembelajaran, (Surabaya: Jp Books, 2007), hal. 63 
lebih baik digunakan untuk kelas dengan jumlah yang sedikit dan tidak terlalu banyak agar siswa tidak malu untuk mengungkapkan pengalamannya. ${ }^{16}$

\section{Hasil Belajar Siswa}

\section{Pengertian hasil belajar}

Menurut kamus bahasa Indonesia hasil adalah sesuatu yag ada (terjadi) oleh suatu kerja, berhasil sukses. ${ }^{17}$ Sementara menurut R.Gagne hasil dipandang sebagai kemampuan internal yang menjadi milik orang serta orang itu melakukan sesuatu. ${ }^{18}$. Sedangkan pengertian belajar secara etimologis belajar belajar dari kata "ajar" yang mendapat awalan ber- dan merupakan kata kerja yang mempunyai arti berusaha memperoleh kepandaian.

Belajar sebagai suatu perubahan yang terjadi dalam kepribadian yang menyatakan diri sebagai suatu pola baru dari pada reaksi yang berupa kecakapan sikap, kebiasaan, kepandaian atau suatu proses pengertian. ${ }^{19}$ Definisi tersebut menekankan pada aspek hasil dari suatu proses yaitu adanya perubahan pola kepribadian yang baru. Perubahan tersebut merupakan respons dari adanya stimulus yang diterima oleh seseorang, lingkup perubahan tersebut meliputi semua aspek kepribadian yaitu kognnitif, afektif, dan psikomotor.

Hampir sama dengan pengertian diatas Slameto mengartikkan belajar sebagai proses usaha yang dilakukan seseorang untuk memperoleh suatu perubahan tingkah laku yang baru secara keseluruan sebagai hasil dari pengalamanya sendiri dalam interaksi dengan lingkungannya. ${ }^{20}$

Kemudian menurut James.O.Withaker mendefinisikan belajar sebagai proses dimana tingkah laku ditimbulkan atau diubah melalui latihan atau pengalaman,

\footnotetext{
16 Dede Rosyada,

${ }^{17}$ Hartono, Kamus Praktis Bahasa Indonesia, (Jakarta: Rienika Cipta, 1996), hal. 53

${ }^{18}$ Departemen Agama, Pedoman Pelaksanaan Pembelajaran Tematik, (Jakarta: Direktorrat Jendral Kelembagaan Islam, 2005), hal. 46

${ }^{19}$ Winkell, Psikologi Pengajaran, (Jakarta: Grafindo Persada,1991), hal. 71

${ }^{20}$ Slameto, Belajar dan Faktor-Faktor Yang Mempenggarubinya, (Jakarta: Rieneka Cipta, 1991), hal. 2
} 
disamping itu juga diartikan sebagai proses sebagian tingkah laku melalui pendidikan atau lebih khusus melalui proses latihan. ${ }^{21}$

Dari beberapa definisi diatas terdapat 2 (dua) sudut pandang mengennai pengertian belajar yaitu belajar sebagai suatu hasil dan juga dipandang sebagai proses. Bertolak dari definisi-definisi diatas dapat kita simpulkan bahwa dalam belajar terkandung beberapa hal, yaitu:

a. Adanya perubahan tingkah laku pada diri seseorang yang mengalami proses belajar.

b. Perubahan tersebut sebagai suatu hasil dari respons siswa terhadap stimulus yang diterima, jadi harus dibedakan dengan perubahan yang tidak dihasilkkan dari pengalaman.

c. Usaha-usaha yang dilakukan seseorang baik melalui latihan, pengalaman, interaksi dan pengalamannya.

d. Lingkup perubahan tersebut meliputi aspek kognitif, afekti, dan psikomotor.

Dari definisi yang telah dipaparkan diatas penulis dapat menyimpulkan bahwa hasil belajar yaitu suatu hasil yang telah dicapai setelah mengevaluasi proses belajar mengajar atau setelah mengalami interaksi dengan lingkungannya guna memperoleh ilmu pengetahuan dan akan menimbulkan perubahan tingkah laku yang relative menetap dan tahan lama.

\section{Arti penting belajar}

Belajar adalah fungsi utama dan vital bagi pendidikan, belajar memainkkan peranan yang penting dalam mempertahankkan kehidupan, pada umat manusia banyak sekali perubahan yang tedapat dalam diri manusia yang bergantung pada belajar sehingga yang terdapat dalam diri manusia kembali pada apa dan bagaimana ia belajar.

Dalam perspektif agama, belajar adalah kewajiban bagi setiap muslim dalam rangka memperoleh ilmu pengetahuan sehingga derajat kehidupannya meningkat. ${ }^{22}$ sesuai dengan firman Allah dalam surat Al- mujadalah ayat 11 yang artinya :

${ }^{21}$ Dewi Ketut Sukardi, Bimbingan Dan Penyuluhan Belajar,(Surabaya: Usaha Nasioal,1983), hal. 17 22 Dewi Ketut Sukardi, hal. 22 
"Hai orang-orang yang beriman, apabila dikatakan kepadamu:" berlapanglapanglah dalam majlis", maka lapangkanlah, niscaya allah akan memberi kelapangan untukemu. Dan apabila dikatakean:"berdirilah untunk kamu, maka berdirilah, maka Allah akan meninggikan orangorang yang beriman diantara mu dan orang-orang yang diberi ilmu pengetahuan beberapa derajat. Dan Allah mengetahui apa yang kamu kerjakan".23

Selain itu Allah juga berfirman dalam surat Al- isra' ayat 36 yang artinya :

"Dan janganlah kamu mengikuti apa yang kau tidak mempunyai pengetahuan tentangnya.sesunggubnya pendengaran,penglibatan dan hhati, semuanya itu akan diminta pertanggungan jawabnya", ${ }^{24}$

Karena itu yang dimaksud dalam hal ini adalah berupa pengetahuan yang relevan dengan tuntutan zaman dan bermanfaat bagi kehidupan orang banyak. Untuk mencapai hasil belajar seperti diatas, kemampuan profesionalisme guru sangat dituntut dan siswa dalalm proses belajarnya hendaklah memunculkan pengalaman pengalaman baru yang positif yang mengembangkan aneka kecakapan.

\section{Jenis-jenis hasil belajar}

Jenis hasil belajar pada bidang kognitif.

Istilah kognitif berasal dari cognition yang bersinonim dengan kata knowing yang berarti pengetahuan, dalam arti luas kognisi adalah perolehan, penataan, dan penggunaan pengetahuan. ${ }^{25}$ Menurut para ahli psikologi kognitif, aspek kognitif ini merupakan sumber sekaligus sebagai pengendali aspek-aspek yang lain, yakni aspek afektif dan juga aspek psikomotorik.

Dengan demikian jika hasil belajar dalam aspek kogniitif tinggi maka dia akan mudah untuk berfikir sehingga ia akan mudah memahami dan meyakini materi-materi pelajaran yang di berikan kepadanya serta mampu menangkap pelan-pelan moral dan nilai-nilai yang terkandung didalam materi tersebut. Sebaliknya, jika hasil belajar kognitif .543

${ }^{23}$ Departemen Agama, Al-qur'an dan Terjemahannya, (Jawa Tengah: Mubarokatan Toyyibah, tt), hal

24 Ibid., hal. 283

${ }^{25}$ Dewi Ketut Sukardi. hal. 22. 
rendah maka ia akan sulit untuk memahami materi tersebut untuk kemudian diinternalisasikan dalam dirinya dan diwujudkan dalam perbuatannya. ${ }^{26}$

Jenis hasil belajar pada bidang afektif.

Aspek afektif berkenaan dengan perubahan sikap dengan hasil belajar dalam aspek ini diperoleh melalui internalisasi, yaitu suatu proses kearah pertumbuhan bathiniyah atau rohaniyah siswa, pertumbuhan terjadi ketika siswa menyadari suatu nilai yang terkandung dalam pengajaran agama dan nilai-nilai itu dijadikkan suatu nilai system diri "nilai diri" sehingga menuntun segenap pernyataan sikap, tingkah laku dan perbuatan untuk menjalani kehidupan.

Adapun beberapa jenis kategori jenis aspek afektif sebagai hasil belajar adalah sebagai berikut :
a Menerima (receiving)
b Jawaban (responding)
c Penilaian (valuing)
d Organisasi (organization)
e Karakteristik (characterization)

Jenis hasil belajar pada bidang psikomotor

Adapun mengenai tujuan dari psikomotorik yang dikembangkan oleh Simpson (1966-1967) sebagai berikut :

a Persepsi : Yaitu penggunaan lima panca indra untuk memperoleh kesadaran dalam menerjemahkan menjadi tindakan.

b Kesiapan : Yaitu keadaan siap untuk merespon secara mental, fisik, dan emosional.

c Respon terbimbing. : Yaitu mengembangkan kemampuan dalam aktifitas mencatat dan membuat laporan.

d Mekanisme : Yaitu respon fisik yang telah dipelajari menjadi kebiasaan.

e Adaptasi : Yaitu mengubah respon dalam stimulasi yang baru.

f Organisasi : Yaitu menciptakan tindakan-tindakan baru. ${ }^{27}$

26 Anas Sudijono, Evaluasi Pendidikan, (Jakarta: Raja Grafindo Persada,1996), hal. 50

${ }^{27}$ Oemar Hamalik, Kurikulum Dan Pembelajaran, (Jakarta: Bumi Aksara, 1995), hal. 82 


\section{Indikator hasil belajar}

Indikator yang dijadikan tolak ukur dalam menyatakan bahwa suatu proses belajar mengajar dikatakan berhasil, berdasarkan ketentuan kurikulum yang disempurnakan, dan yang saat ini digunakkan adalah :

a. Daya serap terhadap bahan pelajaran yang telah diajarkan mencapai prestasi tinggi, baik secara individu maupun kelompok.

b. Prilaku yang digariskan dalam tujuan pengajaran atau intruksional khusus (TIK) telah dicapai siswa baik secara individu maupun secara kelompok. ${ }^{28}$

\section{Tingkat keberhasilan}

Setiap proses belajar mengajar selalu menghasilkan hasil belajar, masalah yang dihadapi ialah sampai ditingkat mana prestasi (hasil) belajar yang telah dicapai, sehubungan dengan hal inilah keberhasilan belajar dibagi menjadi beberapa tingkatan atau taraf, antara lain sebagai berikut:

a. Istimewa/maksimal : apabila seluruh bahan pelajaran yang telah diajarkan dapat dikuasai siswa.

b. Baik sekali/optimal : apabila sebagian besar (76\% sd 99\%) bahan pelajaran yang telah dipelajari dapat dikuasai siswa.

c. Baik/minimal : apabila bahan pelajaran yang telah diajarkan hanya $(60 \%$ sd $75 \%)$ dikuasai siswa.

d. Kurang apabila bahan pelajaran yang telah diajarkakn kurang dari $60 \%$ yang dikuasai siswa. ${ }^{29}$

\section{Faktor-faktor yang mempengarui hasil belajar}

Faktor-faktor yang mempengarui hasil belajar banyak sekali macamnya, namun demikian faktor tersebut dapat dibedakan menjadi tiga yaitu, faktor internal, faktor eksternnal, dan faktor pendekatan belajar. ${ }^{30}$

\footnotetext{
${ }^{28}$ Muhammad Uzer Ustman, Upaya Optimamlisasi Kegiatan Belajar Mengajar, (Bandung,:Remaja Rosydakarya, 1993), hal. 3

${ }^{29}$ Syaiful Bahri Djamarah, Strategi Belajar Mengajar,( Jakarta : Rieneka Cipta,1996), hal. 121

${ }^{30}$ Muhibbin Syah,Psikologi Pendidikan,(Bandung :Remaja Rosdakarya,2008), hal. 132
} 


\section{Faktor internal siswa}

Yang dimaksud dengan faktor internal siswa adalah faktoryang menyangkut seluruh pribadi, termasuk fisik, maupun mental dan psikologinya, yang ikut menentukan hasil belajar siswa. Dalam membicarakan faktor internal meliputi 3 macam yakni $:^{31}$

Pertama, Faktor fisiologis. Kondisi umum jasmani dan tonus (tegangan otot) yang menandai tingkat kebugaran organ-organ tubuh dan sendi-sendinya, dapat mempengarui intensitas siswa dalam mengikuti pelajaran, ${ }^{32}$ orang yang dalam keadaan sehat jasmaninya akan berlainan belajarnya dari orang yang kondisi fisiknya lemah.

Faktor jasmaniyah terdiri dari dua macam, yaitu: (a) Faktor kesehatan. Sehat berarti dalam keadaan baik dalam segenap badan beserta bagiannya bebas dari penyakit. Kesehatan adalah keadaan atau hal sehat, kesehatan seseorang berpengaruh terhadap belajarnya. (b) Faktor cacat tubuh. Cacat tubuh adalah sesuatu yang menyebabkan kurang baik atau kurang sempurna mengenai tubuh atau badan. Cacat itu bisa berupa buta, setengah buta, tuli, setengah tuli, patah tulang dan lain-lain. Keadaan cacat tubuh juga mempengaruhi belajar, siswa yang cacat belajarnya juga terganggu, jika hal ini terjadi, hendaknya ia belajar pada lembaga pendidikan khusus atau diusahakan alat bantu agar dapat menghindari atau mengurangi pengaruh kecatatannya itu. ${ }^{33}$

Kedua, Faktor psikologis. Banyak faktor yang termasuk aspek psikologis yang dapat mempengarui kuantitas dan kualitas perolehan pembelajaran siswa. Namun diantara faktor-faktor siswa yang dipandang lebih esensial itu adalah Intelegensi siswa, Sikap siswa, Perhatian, Minat siswa, Bakat siswa, Motivasi siswa, Kematangan, dan Kesiapan.

Ketiga, Faktor kelelahan. Kelelahan pada seseorang walalupun sulit dipisahkan tetapi dapat dibedakan menjadi dua macam, yaitu kelelahan jasmani dan kelelahan rohani. Kelelahan jasmani terlihat dengan lemah lunglainya tubuh dan timbul kecenderungan untuk membaringkan tubuh.

Sedangkan kelelahan rohani dapat dilihat dengan adanya kelesuan dan kebosanan, sehingga minat dan dorongan untuk menghasilkan sesuatu hilang, kelelahan ini dapat

${ }^{31}$ Slameto,Belajar Dan Faktor-Faktor Yang Mempengarubinyya, (Jakarta: Rineka Cipta,1991), hal. 54

32 Muhibbin Syah, loc. cit.

33 Slameto, loc. cit 
terjadi jika terus menerus memikirkan masalah yang dianggap berat tanpa istirahat, menghadapi hal-hal yang sama dan tidak bervariasi, dan mengerjakkan sesuatu yang tidak sesuai dengan bakat, minat dan perhatiannya. Dan faktor kelelahan juga sangat mempengaruhi hasil belajar karena jika siswa sudah lelah maka ia tidak akan semangat dalam belajar. ${ }^{34}$

Faktor eksternal siswa,

Seperti faktor internal siswa, faktor eksternal siswa juga terdiri atas dua macam, yakni: yakni faktor sosial dan faktor non sosial. Pertama, Faktor lingkungan sosial. Yang dimaksud dengan faktor lingkungan sosial adalah seperti para guru, staf adminisrasi, dan teman-teman sekelas dapat mempengaruhi hasil belajar siswa, para guru yang selalu menunjukkan sikap dan prilaku yang simpatik dan memperlihatkan suri tauladan yang baik khususnya dalam hal belajar dapat menjadi daya dorong yang positif bagi kegiatan belajar siswa.

Lingkungan sosial yang lebih banyak mempengaruhi kegiatan belajar ialah orang tua dan keluarga siswa itu sendiri. Sifat-sifat orang tua, praktik penegelolaan keluarga, ketegangan keluarga, dan demografi keluarga (letak rumah), semuanya dapat memberi dampak baik atupun buruk terhadap kegiatan belajar dan hasil yang dicapai oleh siswa. ${ }^{35}$

Kedua, faktor non sosial. Faktor-faktor yang termasuk lingkungan non sosial antara lain, ialah: keadaan udara, suhu udara,cuaca, waktu (pagi, siang dan malam), tempat (letaknya, pergedungannya), alat-alat yang dipakai untuk belajar (seperti alat tulismenulis, buku-buku, alat peraga). Selama ini faktor-faktor diatas sangat mempengarui hasil belajar siswa. ${ }^{36}$

Ketiga, Faktor pendekatan belajar. Pendekatan belajar adalah segala cara atau strategi yangdigunakan siswa untuk menunjang keefektifan dan efisiensi dalam proses pembelajaran materi tertentu, ${ }^{37}$ dan selain faktor internal dan faktor eksternal, faktor pendekatan belajar juga berpengaruh terhadap taraf keberhasilan belajar siswa tersebut

\footnotetext{
${ }^{34}$ Ibid.

${ }^{35}$ Muhibbin Syah, hal. 137-138

${ }^{36}$ Sumadi Suryabrata, Psikologi Pendidikan, (Jakarta : Raja Grafindo Persada, 2008), hal. 233

${ }^{37}$ Muhibbin Syah, hal. 139.
} 


\section{Pembelajaran Fiqih di Madrasah Ibtidaiyah}

\section{Pengertian}

Pelajaran fiqh diarahkan untuk mengantarkan peserta didik dapat memahami pokok-pokok hukum islam dan tata cara pelaksanaanya untuk diaplikasikan dalam kehidupan sehingga menjadi muslim yang selalu ta'at menjalankan syari'at islam secara kaffah.

\section{Tujuan pembelajaran fiqh}

Pembelajaran fiqh di Madrasah Ibtidaiyah bertujuan untuk membekali siswa antara lain agar dapat:

a Mengetahui dan memahami pokok-pokok hukum islam dalam mengatur ketentuan dan tata cara menjalankan hubungan manusia dengan Allah yang diatur dalam fiqh ibadah dan hubungan manusia dengan sesama yang diatur dalam figh muamalah.

b Melaksanakan dan mengamalkan ketentuan hukum islam dengan benar dalam melaksanakan ibadah kepada Allah dan ibadah sosial. Pengalaman tersebut diharapkan menumbuhkan ketaatan menjalankan hukum islam, disiplin dan tanggung jawab sosial yang tinggi dalam kehidupan pribadi maupun sosial. ${ }^{38}$

\section{Ruang lingkup mata pelajaran fiqh}

Ruang lingkup fiqh Madrasah Ibtidaiyah meliputi ketentuan pengaturan hukum Islam dalam menjaga keserasian, keselarasan, dan keseimbangan antara hubungan manusia denggan Allah SWT dan hubungan manusia dengan sesama manusia. Adapun ruang lingkup mata pelajaran Fiqh di Madrasah Ibtidaiyah meliputi :

a Aspek fiqh ibadah meliputi : ketentuan dan tata cara thaharoh, shalat fardhu, shalat sunnah, dan shalat dalam keadaan darurat, sujud, adzan dan iqomah, berdzikir dan berdo'a setelah shalat, puasa, zakat, haji dan umrah, kurban dan aqiqah, makanan, perawatan jenazah, dan ziarah kubur.

${ }^{38}$ Peraturan Menteri Agama RI, No 2 Tahun 2008 Tentang Standar Kompetensi Lulusan Dan Standar Isi Pendidikan Agama Island Dan Bahasa Arab Di Madrasah, (Mapemda Kanwil Depag.Prof Jawa Timur, Diirektora Jendral Pendidikan Islam,2008), hal. 76-77 
b Aspek fiqh muamalah meliputi : ketentuan dan hukum jual beli, qirad, riba, pinjam meminjam, utang piutang, gadai,dan borg, serta upah. ${ }^{39}$

\section{Pengaruh Strategi Critical Incident (Pengalaman Penting) Terhadap Hasil Belajar Siswa}

Strategi pembelajaran adalah suatu hal yang penting di dalam sebuah proses belajar mengajar dan untuk saat ini dalam pembelajaran yang dibutuhkan adalah strategistrategi yang bisa membuat siswa aktif dalam mengikuti semua proses belajar mengajar, dan salah satu strategi yang bisa mengaktifkan siswa adalah Strategi critical incident (pengalaman penting) yaitu strategi yang mana siswa diminta untuk mengingat-ingat pengalamannya yang berhubungan dengan materi-materi yang dipelajari kemudian siswa disuruh untuk mengungkapkan pengalamannya tersebut, dengan adanya strategi ini siswa dituntut untuk selalu belajar dari segala yang telah mereka lakukan.

Dengan adanya pengalaman yang dimiliki siswa maka mereka akan lebih mudah ketika menangkap pelajaran yang dipelajari, begitu juga ketika mereka harus mendemonstrasikan materi-materi yang telah mereka pelajari. Dan dengan adanya kemudahan siswa dalam menerima dan menagkap materi pelajaran maka secara tidak langsung juga akan mempengaruhi hasil belajar siswa.

\section{KESIMPULAN}

Strategi critical incident ( Pengalaman Penting) adalah strategi untuk mengaktifkan siswa sejak dimulainya pembelajaran yaitu strategi yang mana siswa harus mengingat dan mendiskripsikan pengalaman masa lalunya yang sesuai dengan topik materi yang disampaikan.

Strategi critical incident (pengalaman penting) yaitu suatu strategi yang mana siswa harus mengingat dan mendiskripsikan pengalaman masa lalunya yang menarik dan berhubungan serta berkaitan dengan pokok bahasan yang akan disampaikan, lalu guru menyampaikan materi dengan menghubungkan pengalaman yang dimiliki oleh siswanya.

${ }^{39}$ Ibid., hal. 79-80 
Menurut kamus bahasa Indonesia hasil adalah sesuatu yag ada (terjadi) oleh suatu kerja, berhasil sukses. Sementara menurut R.Gagne hasil dipandang sebagai kemampuan internal yang menjadi milik orang serta orang itu melakukan sesuatu. Sedangkan pengertian belajar secara etimologis belajar belajar dari kata "ajar" yang mendapat awalan ber- dan merupakan kata kerja yang mempunyai arti berusaha memperoleh kepandaian.

Pelajaran fiqh diarahkan untuk mengantarkan peserta didik dapat memahami pokok-pokok hukum islam dan tata cara pelaksanaanya untuk diaplikasikan dalam kehidupan sehingga menjadi muslim yang selalu ta'at menjalankan syari'at islam secara kaffah.

\section{DAFTAR PUSTAKA}

Undang-undang RI, Tentang System Pendidikan Nasional, Bandung: Citra Umbara, 2003.

Muhibbin Syah, Psikologi Belajar, Jakarta: Raja Grafindo Persada, 2002.

Amir Daien Indrakusuma, Pengantar Ilmu Pendidikan, Surabaya: Usaha Nasional. 2006

Koestoer Partowisastro, Dinamika Dalam Psikologi Pendidikan, Jakarta: Erlangga,1983.

Melvin L Silberman, Active Learning 101 Cara Belajar Siswa Aktif, Bandung: Nusa Media, 2006.

Syaharuddin, http :/syaharuddin. Wordpress.com/2008/04/25/mengurrangi kebosanan siswa melalui berbagai strategi mengajar /

http :/syaharuddin. Wordpress.com/2008/04/25/mengurrangi kebosanan siswa melalui berbagai metode mengajar /

Dede Rosyada, et. al., Pendidikan Kewargaan, Jakarta: Prenada Media, 2004.

Ahmad Sabri, Strategi Belajar Mengajar dan Micro Teacbing, Ciputat: Quantum Teaching, 2005.

http://ghufroon-nuddaroin.blogspot.com/2009/02/manajemen-pembelajaran.html.

Suwardi, Manajemen Pembelajaran, Surabaya: Jp Books, 2007.

Hartono, Kamus Praktis Bahasa Indonesia, Jakarta: Rienika Cipta, 1996.

Departemen Agama, Pedoman Pelaksanaan Pembelajaran Tematik, Jakarta: Direktorrat Jendral Kelembagaan Islam, 2005.

Winkell, Psikologi Pengajaran, Jakarta: Grafindo Persada,1991.

Slameto, Belajar dan Faktor-Faktor Yang Mempenggarubinya, Jakarta: Rieneka Cipta, 1991.

Dewi Ketut Sukardi, Bimbingan Dan Penyuluhan Belajar,Surabaya: Usaha Nasioal,1983. 
Suparlan

Departemen Agama, Al-qur'an dan Terjemahannya, Jawa Tengah: Mubarokatan Toyyibah,

$\mathrm{tt}$

Anas Sudijono, Evaluasi Pendidikan, Jakarta: Raja Grafindo Persada,1996.

Oemar Hamalik, Kurikulum Dan Pembelajaran, Jakarta: Bumi Aksara, 1995.

Muhammad Uzer Ustman, Upaya Optimamlisasi Kegiatan Belajar Mengajar, Bandung,:Remaja Rosydakarya, 1993.

Syaiful Bahri Djamarah, Strategi Belajar Mengajar, Jakarta : Rieneka Cipta,1996.

Muhibbin Syah,Psikologi Pendidikan, Bandung :Remaja Rosdakarya,2008.

Slameto,Belajar Dan Faktor-Faktor Yang Mempengarubinyya, Jakarta: Rineka Cipta,1991.

Sumadi Suryabrata, Psikologi Pendidikan, Jakarta : Raja Grafindo Persada, 2008.

Peraturan Menteri Agama RI, No 2 Tahun 2008 Tentang Standar Kompetensi Lulusan Dan Standar Isi Pendidikan Agama Island Dan Bahasa Arab Di Madrasah, Mapemda Kanwil Depag.Prof Jawa Timur, Diirektora Jendral Pendidikan Islam, 2008. 